\title{
Study of rice genotypes and their use in the process of selection
}

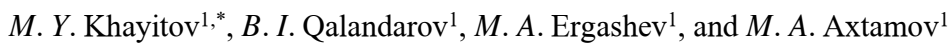 \\ ${ }^{1}$ Tashkent State Agrarian University, Universitetskaya str., 2, 100140, Tashkent, Uzbekistan
}

\begin{abstract}
This research was aimed the use of non-traditional, biochemical marker-based selection methods in synchronization with classical methods in rice selection, rapid adaptation to adverse environmental factors, disease tolerance, lodging and shedding resistance, high yield and technological quality of rice. According to the results of the experiment, 42 varieties in 2018, 28 in 2019 and 39 in 2020 with a total of 109 combinations of 7172 flowers were selected with the participation of varieties and specimens that are resistant to various environmental influences and diseases, high yield, high grain quality. was carried out. The results of the hybridization showed that 118 (or 3.78\%) in 2018, 117 (or $5.35 \%$ ) in 2019,81 (or $4.35 \%$ ) in 2020 , a total of 316 (or $4.4 \%$ ) hybrid populations were taken. $F_{1}$ generation hybrids obtained from the combinations of Chongwang x TShD 15-13 and Chongwang x 227-09, was recommended not to use these combinations in future studies due to the low dominance of "Ruvak" (paniculo is a type of plant inflorescence) length and 1000 grain weight.
\end{abstract}

\section{Introduction}

Rice is the most important food crop in the world, the second largest in terms of area under cultivation in the world, and the first in terms of yield among cereals [1]. According to the U.S. Department of Agriculture (USDA), in 2018, 765.6 million tons of rice were grown. In particular, 224.6 million tons of rice were harvest in China, followed by 176.9 million tons in India, 56.1 million tons in Indonesia, 54.6 million tons in Bangladesh, 43.5 million tons in Vietnam, 31.5 million tons in Thailand 20.5 million tons in Burma, 18.4 million tons in the Philippines, 12 million tons in Japan and 11.5 million tons in Pakistan [2]. In order to ensure food security in a number of developed rice-growing countries of the world, grain quality has been improved and high yields and economic efficiency has been achieved through the creation, selection, rational placement of varieties suitable for soil and climatic conditions, scientifically based application of advanced resource-saving technologies.

Today, about 450,000 tons of rice have been harvested from about 115,000 hectares of agricultural land in Uzbekistan, and the average amount of rice per capita was 7.6

\footnotetext{
${ }^{*}$ Corresponding author: m.y.xayitov@yandex.uz
} 
kilograms. However, this did not meet with demand of the state population for rice, consequently, in 2019, 58.7 thousand tons of rice products were imported from foreign countries. In recent years, comprehensive reforms have been carried out in the country to develop agriculture. In particular, the Resolution of the Cabinet of Ministers of the Republic of Uzbekistan dated December 12, 2019 No. 986 "On additional measures for the development of rice" was adopted. Accordingly, the Karakalpak Scientific Experimental Station of the Rice Research Institute, rice clusters, the Association "Uzbeksholichilik" was established. The ongoing reforms are aimed at increasing rice production in the country, stable supply of the domestic consumer market with rice products and increasing export potential. For this, the rational use of land and water resources, the creation, selection of new varieties of agricultural crops adapted to local soil and climatic conditions, serious attention has to consider the introduction of resource-saving modern agro-technologies. In this regard, to conduct research on the development and introduction of new varieties of rice with high quality, resistant to adverse environmental conditions, diseases and pests, is vitally important towards increasing productivity in rice cultivation, improving grain quality and meeting the demand of the population for rice products [1-3, 5].

The selection process can be carried out in traditional classical or non-traditional selection methods, and its success depends on the effectiveness of the selection methods. Based on the traditional selection methods in use, breeders have the ability to distinguish only ridges with certain genotypes from hybrid populations. All varieties of rice grown in the country are based on traditional (classical) selection methods, based on the ability of selection scientists to select genotypes that combine morphological and physiological characteristics [4]. The traditional selection process is a 10-12-year process consisting of painstaking research involving multiple selections, tests in different climatic conditions [4, $6]$. Therefore, the changing soil and climatic conditions and the corresponding changes in requirements require the use of non-traditional methods and technologies that would help to accelerate the creation of new varieties. Therefore, in today's plant selection, the development of selection in cultivated plants on the basis of non-traditional methods, and the study of indicators controlled by individual genes or groups of genes based on modern biochemical markers are developing $[4,5]$. Molecular modern biochemical markers (MAS) technologies of biology play a special role in determining the level of salinity resistance of plants. Because protein molecules in a plant cell are an unchanging quality indicator [5-8]. Based on the above-mentioned points, this research was aimed the use of non-traditional, biochemical marker-based selection methods in synchronization with classical methods in rice selection, rapid adaptation to adverse environmental factors, disease tolerance, lodging and shedding resistance, high yield and technological quality of rice. Accordingly, following research objectives were formulated: 1) study, evaluation and selection of varietal samples, hybrids and ridges as primary sources, valuable economic characteristics, adaptability to adverse environmental factors and disease resistance, 2) mixing of selected parent pairs, and 3) evaluation and selection of valuable economic traits in hybrid populations, characteristics of adaptability to adverse environmental factors, disease immunity, resistance to lodging and shedding [3-6].

\section{Materials and methods}

The research was conducted in the experimental fields of the Rice Research Institute, that was, in 2018 and 2020 on an area of 1.30 hectares on the 3rd edge of 12 cards, and on 
1.07 hectares area on the 2 nd edge of 13 cards in 2019. The experimental fields of the Institute are located in the south-eastern part of the Tashkent region, on the left bank of the Chirchik River, and geographical location is $41^{\circ} 11^{\prime} 16$ "north latitude and $69^{\circ} 20^{\prime} 07^{\prime \prime}$ east longitude (Figure 1). The topography of the area was flat, the soil layer in the experimental fields encompassed gray meadow and meadow swampy soils. The driving layer was 0-30 and 0-40 cm, below the driving layer was a layer of gel 30-40 cm thick, at a depth of 60-70 $\mathrm{cm}$ there was a layer of sand and small stones. The sandy and fine-grained layer was also found at 30-40 $\mathrm{cm}$ in some parts of the experimental area. Moreover, the amount of physical mud of soil in 0-30 cm depth was $51.9 \%$, followed by $\mathrm{pH}$ amount accounted for 7.3 (Table 1). There were no mineral salts due to the fact that the soils of the experimental area were composed of sand and gravel, and the groundwater flows from the northeast to the southwest. In the same soil depth, the amount of humus was $1.86 \%$, Nitrogen N-NO3 $\mathrm{mg} / \mathrm{kg}$ was 22.4, Phosphorus P2O5 mg/kg was 84, and Potassium K2O mg/kg was 17.6 (Table 2).

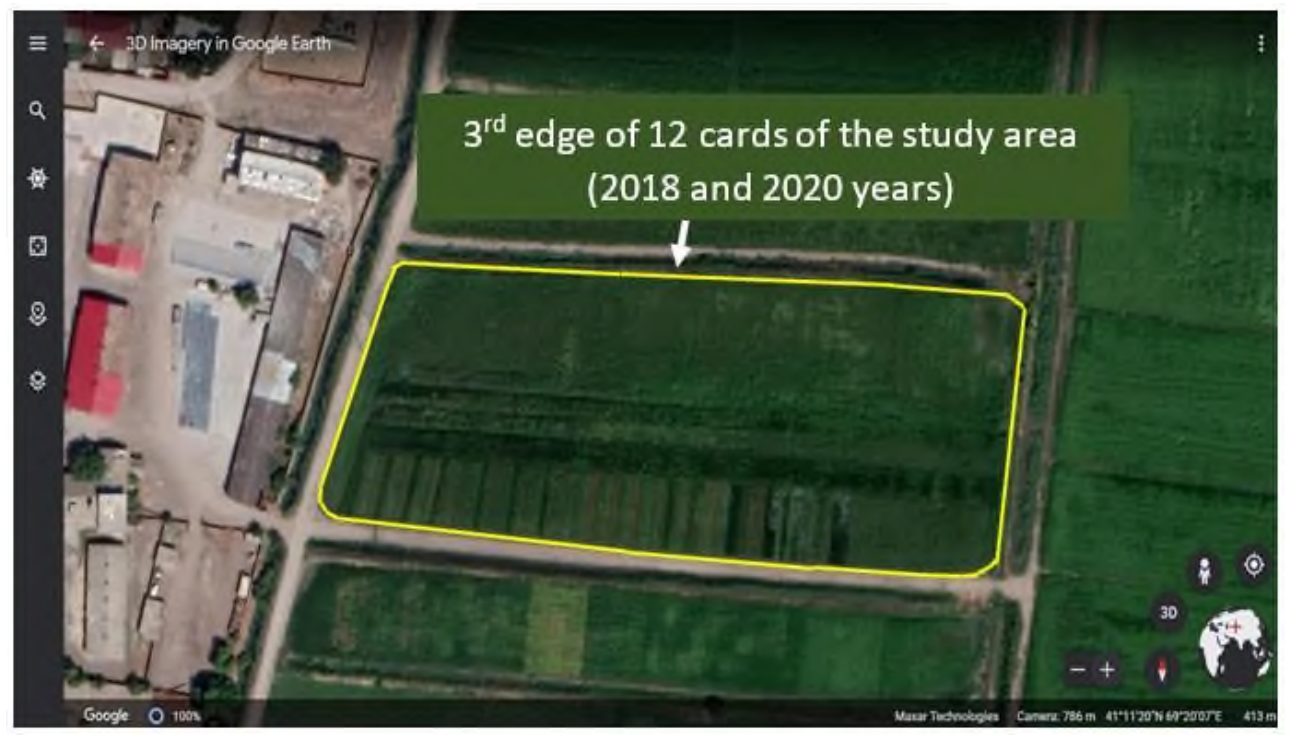

Fig. 1. Study area

Table 1. Mechanical composition, salinity and $\mathrm{pH}$ of the soil of the experimental area

\begin{tabular}{|c|c|c|c|c|c|}
\hline \multirow{2}{*}{ Depth } & \multirow{2}{*}{$\begin{array}{c}\text { Amount of } \\
\text { physical } \\
\text { mud,\% }\end{array}$} & \multirow{2}{*}{$\begin{array}{c}\text { Mechanical } \\
\text { structure }\end{array}$} & \multicolumn{2}{|c|}{ Salinity } & \multirow{2}{*}{$\begin{array}{c}\text { pH } \\
\text { amount }\end{array}$} \\
\cline { 4 - 5 } & & Type & Degree & \\
\hline $0-30$ & 51.9 & Medium sand & Sulfate & No saline & 7.3 \\
\hline
\end{tabular}

Table 2. The amount of humus and nutrients in the soil of the experimental area

\begin{tabular}{|c|c|c|c|c|}
\hline Depth, cm & Humus, \% & $\begin{array}{c}\text { Nitrogen N- } \\
\text { NO3 } \mathbf{~ m g / k g ~}\end{array}$ & $\begin{array}{c}\text { Phosphorus } \\
\text { P2O5 } \mathbf{~ m g / k g ~}\end{array}$ & $\begin{array}{c}\text { Potassium } \\
\text { K2O } \mathbf{~ m g / k g}\end{array}$ \\
\hline $0-30$ & 1.86 & 22.4 & 84 & 17,6 \\
\hline
\end{tabular}


Air temperature and relative humidity vary in different years. These meteorological factors have a significant impact on the growth and development of rice, as well as other agricultural crops. According to long-term data from the Tuyaboguz meteorological station, the average air temperature during the year was $12.3{ }^{\circ} \mathrm{C}$, and the highest air temperature in July was $+34.5^{\circ} \mathrm{C}$ degrees. The coldest temperature was minus $6-8{ }^{\circ} \mathrm{C}$ in January, and in some years, and it was dropped to minus $10-15{ }^{\circ} \mathrm{C}$, but winter rarely comes cold $[5,6]$.

Field experiments were conducted based on the methodology of the All-Russian Rice Research Institute, whereas statistical analysis of the results was obtained using the method of B.A. Dospekhov [5]. Phenological observations were carried out in accordance with the manual "State Variety Testing of Agricultural Crops". During the period from germination to full ripening of the rice plant (harvesting, pruning, rooting, flowering and ripening), it was observed that all crops undergo the same developmental phases at the same time [9, 10]. At the end of the growing season, before harvest, in order to determine the biometric parameters, biometric analysis was carried out in the laboratory under sample conditions from $1 \mathrm{~m}^{2}$ area at 3 points of each plot. In this case, parameters were plant height, number of productive stems, length of the plate, the number of grains in the husk, including the number of whole and empty grains, grain weight per grain, 1000 grain weight, and accumulatio rate. The crop in each plot was harvested to determine the yield. The quality of the grain was determined in a special laboratory. The grain size of the ridges in the varietal selection test was determined by the measurement method. In this case, 15 grains of each ridge were taken and a series was analyzed, and the total length, width and thickness were measured. The result was divided by 15 to determine the average grain, rice length, width, and thickness [10].

As a standard, 425 cultivars were planted in the collection nursery in 2018-2020. Phenological observations were made on the planted cultivars and the phases of germination, accumulation, tubing, flowering and ripening were determined. Plant height was important in creating new varieties of rice. Therefore, the morphology of the cultivars was initially studied on the basis of plant height $[9,10]$. Accordingly, all cultivars were divided into 5 groups: low-growing $(65-84 \mathrm{~cm})$ specimens, medium-sized $(85-104 \mathrm{~cm})$ specimens, medium-tall $(105-124 \mathrm{~cm})$, long-stemmed $(125-144 \mathrm{~cm})$, and very. classified into tall (above $145 \mathrm{~cm}$ ) specimens. Twenty-two specimens were included in the group of low-height specimens, 43 in the group of medium-height specimens, 96 in the group of medium-length specimens, 223 in the group of tall specimens, and 41 in the group of very tall specimens (Figure 2).

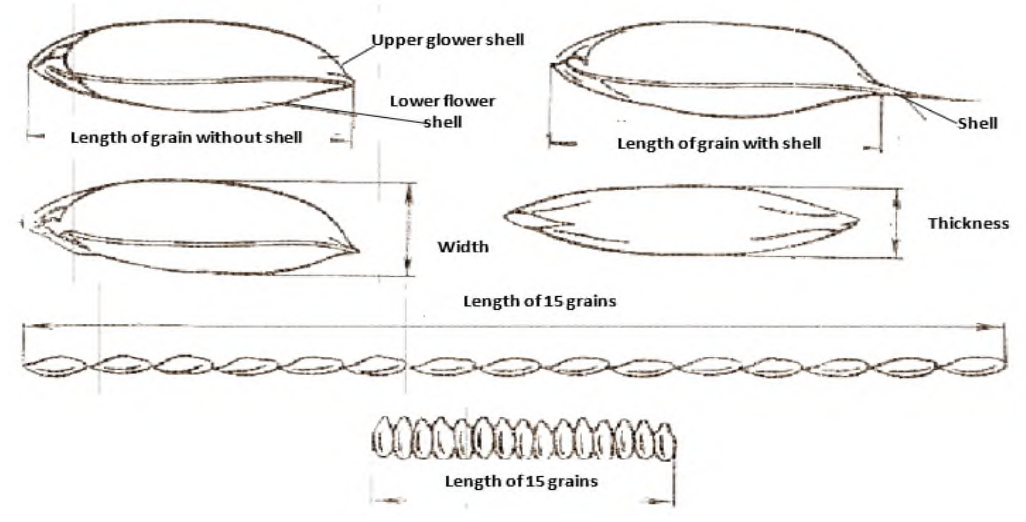

Fig. 2. Method for determining grain size 


$$
\text { hp, } \frac{F-M p}{P-M p}
$$

The dominance of plant height, stalk length, and grain weight per 1000 grains in the F1 generation hybrid combinations studied was determined by the following formula:

Where:

$\mathbf{h p}$ is the dominance level

$\mathbf{F}$ is the arithmetic mean of the hybrid

$\mathbf{R}$ is thearithmetic mean of theparent form with a high value

$\mathrm{Mr}$ is the parent arithmetic mean of shapes [5]

\section{Results and discussion}

\subsection{Biometric parameters}

During the ripening period, model samples were taken from each variety and biometric parameters were determined in the laboratory. Biometric indicators included the main characteristics of the crop: height, yield, length of stalks, weight of 1000 grains. Grain shape determines the technological quality of the variety. When the samples in the collection nursery were divided into long (indica) and round (japonica) grains according to the shape of the grain, the long grains were 125 grains and the round grains were 300 grains. Depending on the growing season, the cultivars were divided into 4 groups: very early, early, middle and late. The vegetation period of the selected cultivars was up to 105 days in the very early maturing group (k-242, k-243, k-244, k-246, k-247, k-257, k-266, k269 , k-270, k. -296, k-297), in the early maturing group from 105 to 115 days (k-61, k-79, k-82, k-88, k-94, k-101, k-230, k-231, k-268, k-404), in the middle-aged group from 115 to 125 days (k-21, k-42, k-43, k-223, k-229, k-292, k-316, k-325, k-389, k-390, k-391, k406, k-417, k-424), more than 125 days in the late maturing group (k-1, k-3, k-6, k-17, k53, k-55, k-103, k-115, k-138, k-146) (Figures 3 and 4).

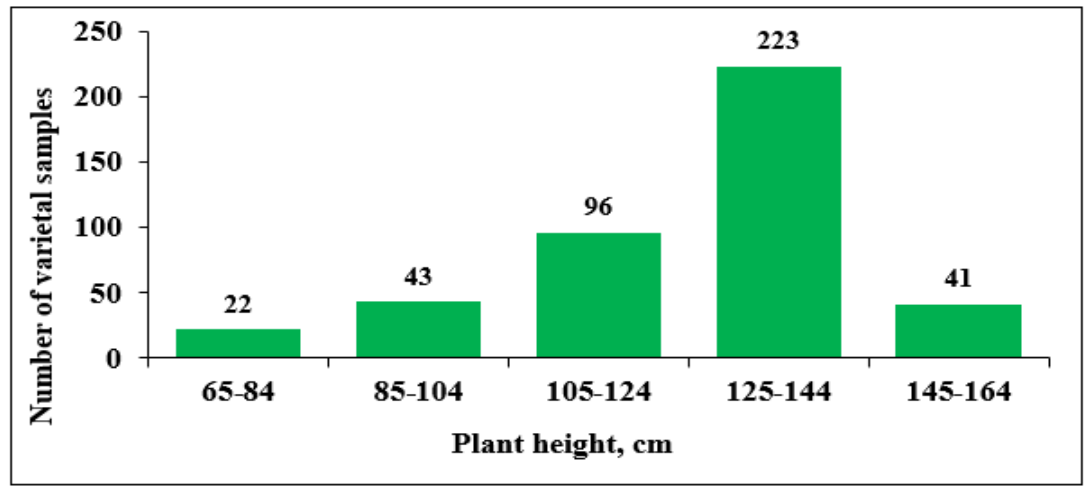

Fig. 3. Classification of collection cultivars by plant

A total of 425 cultivars available in the collection nursery were divided into 6 groups as a result of measuring the length of the stalk. Including 13-15 cm (7 pieces), 16-18 cm (37 pieces), 19-21 cm (94 pieces), 22-24 cm (136), 25-27 cm (107 pieces) and 28-30 cm (44) as 
illustrated in Figure 5. K-243 (30.5 g), k-270 (32.8 g) and k-297 (35.2 g) from the ultraearly group by weight of 1000 grains of 30 varieties obtained as a result of selection for use in future research. k-268 (33.4 g), k-231 (34.7 g) and k-82 (32.3 g) varieties from the early maturing group, k-43 (34.5 g) from the middle-aged group, k-223 (33.9 g) and k-389 (36.1 g) and k-103 (35.5 g) varieties were selected from the late ripening group (Figure 6). When analyzing the yield of the selected cultivars, it was observed that the yield of a total of 425 cultivars ranged from 10 to 90 quintals. Including 6 in the range of 10-20 quintals, 13 in the range of 20-30 quintals, 4 in the range of 30-40 quintals, 5 in the range of 40-50 quintals, 64 in the range of 50-60 quintals, 111 in the range of 60-70 quintals, 70 It was found that there were 174 in the range of -80 quintals and 47 in the range of 80-90 quintals (Figure 7).

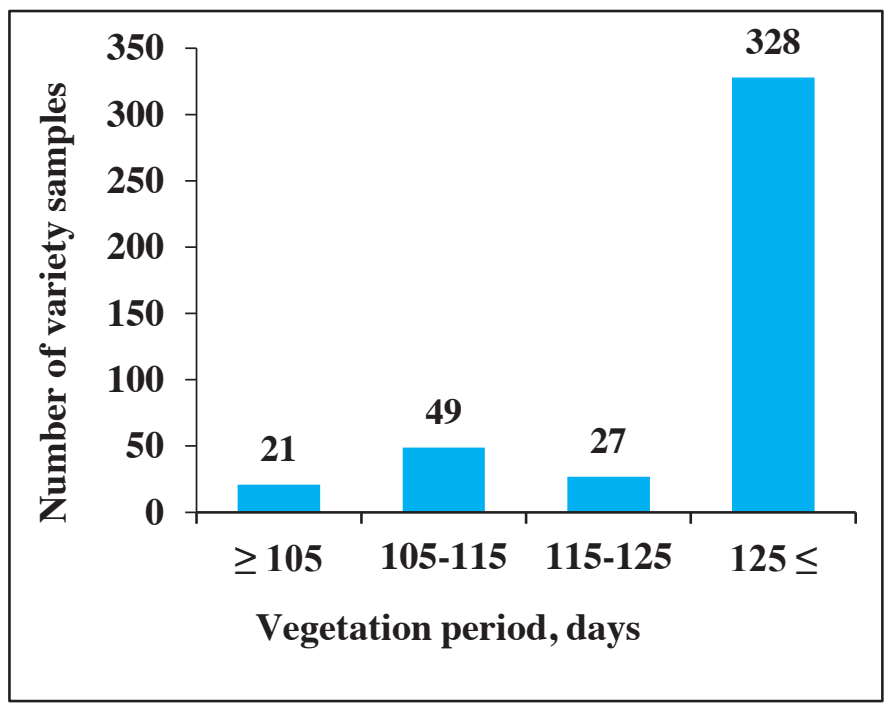

Fig. 4. Grouping of collection varieties by vegetation period

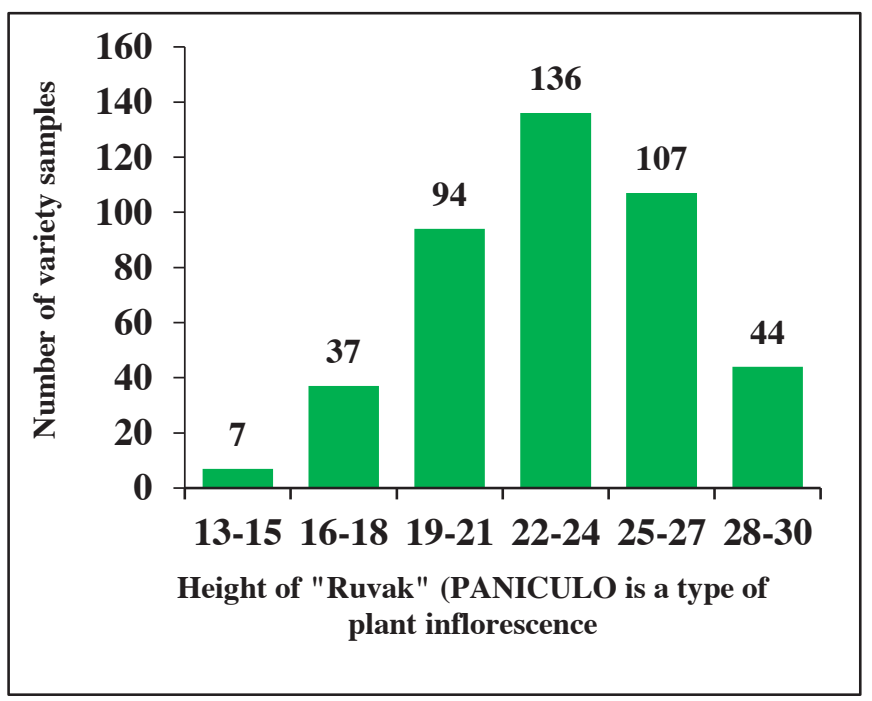

Fig. 5. Classification of collection varieties by "Ruvak" (paniculo) 


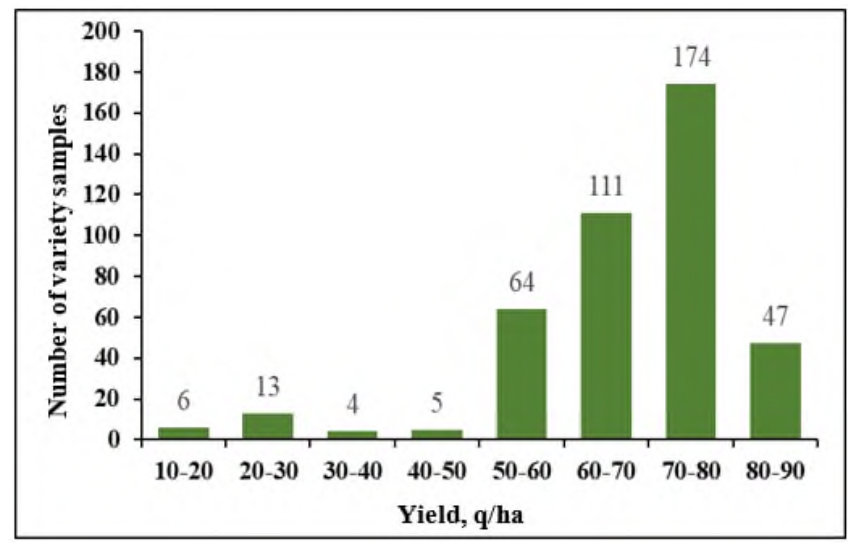

Fig. 6. Grouping of collection varieties by yield index.

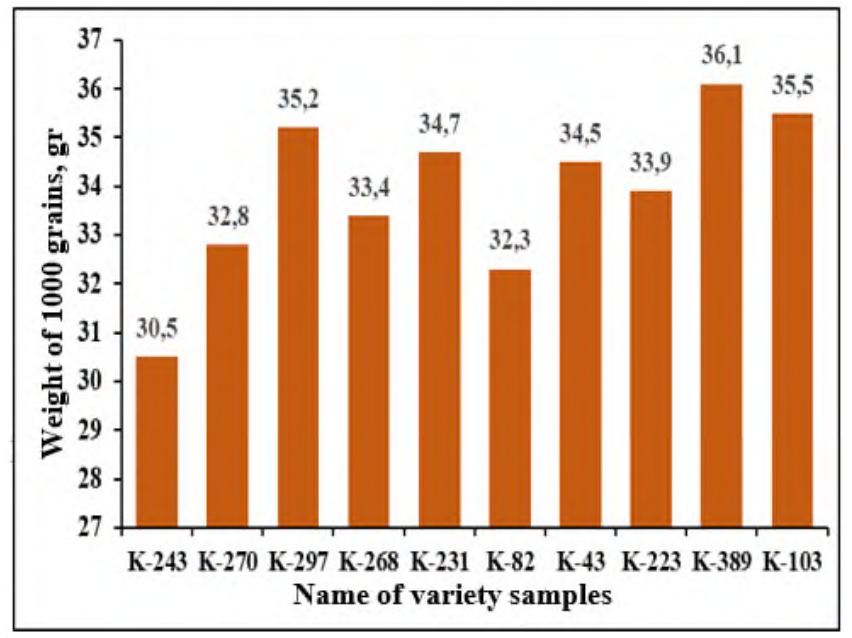

Fig. 7. Selected collection varieties on 1000 grain weight

\subsection{Mixing and hybrid seedlings}

When selective scientists create varieties suitable for each region, it is important to select the right target genotypes and parental forms for crossbreeding, which are mainly high-yielding. Heterosis is most pronounced in their hybrids when the parental forms are biologically and genetically different. As a result of hybridization of rice varieties that are geographically distant, the basis for the emergence of genetically productive hybrids formed in different places in the plant genetics, which in themselves reflect the characteristics of the parent forms that appear in different environmental conditions. The most important thing in selection is a specific genotype or homo-heterozygous and other indicators of fertility, i.e., what genetic potential it has. This is due to the problem of selecting excellent genotypes from hybrid mixtures when hybridizing two factors. During the years of the project, local and foreign varieties recommended for use as parental forms 
were planted in the growing area. In this case, they were planted in 3 periods, synchronizing flowering periods with each other.

The rice plant was fed with mineral fertilizers and carefully cared for in the water regime for good growth and development. With the onset of the flowering phase, interbreeding was carried out in the furrows, which are suitable for the best developed plants. According to the results of the experiment, 42 varieties in 2018, 28 in 2019 and 39 in 2020 with a total of 109 combinations of 7172 flowers were selected with the participation of varieties and specimens that are resistant to various environmental influences and diseases, high yield, high grain quality. was carried out. According to the results of the hybridization, 118 (or $3.78 \%$ ) in 2018,117 (or $5.35 \%$ ) in 2019,81 (or $4.35 \%$ ) in 2020, a total of 316 (or $4.4 \%$ ) hybrid populations were obtained (Table 3 ).

Table 3. Results of hybridization

\begin{tabular}{|c|c|c|c|c|c|}
\hline \multirow{2}{*}{ № } & \multicolumn{2}{|c|}{ Combination } & \multirow{2}{*}{$\begin{array}{c}\text { The number of } \\
\text { hybridized } \\
\text { flowers, pieces }\end{array}$} & \multicolumn{2}{|c|}{$\begin{array}{c}\text { The number of } \\
\text { hybridized seeds }\end{array}$} \\
\hline & q & $0^{\lambda}$ & & pieces & $\%$ \\
\hline 1. & Polizesti 28 & Iskandar & 22 & 1 & 4.55 \\
\hline 2. & Dongjin & Lazurniy & 125 & 3 & 2.4 \\
\hline 3. & \multirow{4}{*}{ Iskandar } & Jinmi & 121 & 3 & 2.48 \\
\hline 4. & & Lazurniy & 112 & 2 & 1.79 \\
\hline 5. & & Unkwang & 119 & 3 & 2.52 \\
\hline 6. & & Baekilmi & 124 & 5 & 4.03 \\
\hline 7. & \multirow{4}{*}{ Osmancik-97 } & Iskandar & 101 & 2 & 1.98 \\
\hline 8. & & Sharm & 106 & 3 & 2.83 \\
\hline 9. & & Tursunboy & 120 & 6 & 5.0 \\
\hline 10. & & Osmancik-97 & 100 & 4 & 4.0 \\
\hline 11. & \multirow{4}{*}{$227-09$} & Favorite & 80 & 2 & 2.5 \\
\hline 12. & & Osmancik-97 & 80 & 3 & 3.75 \\
\hline 13. & & Favorite & 20 & 1 & 5.0 \\
\hline 14. & & Sanam & 40 & 1 & 2.50 \\
\hline 15. & Osmancik-97 & Favorite & 220 & 6 & 2.73 \\
\hline 16. & Ilgor & Sharm & 101 & 3 & 2.97 \\
\hline 17. & \multirow{5}{*}{ Nukus-2 } & Iskandar & 60 & 3 & 5.0 \\
\hline 18. & & Sharm & 41 & 3 & 7.32 \\
\hline 19. & & Tursunboy & 40 & 3 & 7.5 \\
\hline 20. & & Osmancik-97 & 81 & 4 & 4.94 \\
\hline 21. & & Sanam & 39 & 3 & 7.69 \\
\hline 22. & \multirow{3}{*}{ Guljahon } & Sharm & 20 & 1 & 5.0 \\
\hline 23. & & Osmancik-97 & 59 & 5 & 8.47 \\
\hline 24. & & Iskandar & 89 & 6 & 6.74 \\
\hline
\end{tabular}




\begin{tabular}{|c|c|c|c|c|c|}
\hline \multirow{2}{*}{ № } & \multicolumn{2}{|c|}{ Combination } & \multirow{2}{*}{$\begin{array}{l}\text { The number of } \\
\text { hybridized } \\
\text { flowers, pieces }\end{array}$} & \multicolumn{2}{|c|}{$\begin{array}{c}\text { The number of } \\
\text { hybridized seeds }\end{array}$} \\
\hline & q & o & & pieces & $\%$ \\
\hline 25. & & Novator & 88 & 2 & 2.27 \\
\hline 26. & \multirow{5}{*}{ Mustakillik } & Vikant & 19 & 1 & 5.26 \\
\hline 27. & & Osmancik-97 & 40 & 2 & 5.0 \\
\hline 28. & & Tantana & 19 & 1 & 5.26 \\
\hline 29. & & Sanam & 56 & 3 & 5.36 \\
\hline 30 . & & Iskandar & 56 & 2 & 3.57 \\
\hline 31. & \multirow{3}{*}{ Iskandar } & Osmancik-97 & 64 & 1 & 1.56 \\
\hline 32. & & Sanam & 40 & 2 & 5.0 \\
\hline 33. & & Viktoriya & 41 & 2 & 4.88 \\
\hline 34. & \multirow{6}{*}{ Tantana } & Viktoriya & 80 & 6 & 7.5 \\
\hline 35. & & Osmancik-97 & 40 & 3 & 7.5 \\
\hline 36. & & Novator & 20 & 1 & 5.0 \\
\hline 37. & & Iskandar & 88 & 3 & 3.41 \\
\hline 38. & & Sharm & 87 & 3 & 3.45 \\
\hline 39. & & Tursunboy & 64 & 2 & 3.13 \\
\hline 40. & \multirow{3}{*}{ Lazurniy } & Osmancik-97 & 100 & 3 & 3.0 \\
\hline 41. & & Sanam & 100 & 2 & 2.0 \\
\hline 42. & & Favorite & 98 & 3 & 3.06 \\
\hline 43. & \multirow{4}{*}{ Sonet } & Iskandar & 105 & 0 & 0 \\
\hline 44. & & $\begin{array}{c}\text { TSHD 15-13-1-1-1- } \\
1 \\
\end{array}$ & 75 & 0 & 0 \\
\hline 45. & & Chongwan & 16 & 0 & 0 \\
\hline 46. & & 227-09 & 55 & 1 & 1.8 \\
\hline 47. & Polizesti & Iskandar & 110 & 17 & 15.5 \\
\hline 48. & \multirow{2}{*}{$\begin{array}{c}\text { TSHD 20-13- } \\
1-1-1-1\end{array}$} & Iskandar & 120 & 9 & 7.5 \\
\hline 49. & & $\begin{array}{c}\text { TSHD 15-13-1-1-1- } \\
1\end{array}$ & 35 & 7 & 20.0 \\
\hline 50. & \multirow{3}{*}{ Jinbu } & $\begin{array}{c}\text { TSHD 15-13-1-1-1- } \\
1\end{array}$ & 18 & 0 & 0 \\
\hline 51. & & Chongwan & 90 & 6 & 6.7 \\
\hline 52. & & $\begin{array}{c}\text { TSHD 20-13-1-1-1- } \\
1\end{array}$ & 56 & 7 & 12.5 \\
\hline 53. & \multirow{4}{*}{ Chongwan } & $\begin{array}{c}\text { TSHD 15-13-1-1-1- } \\
1 \\
\end{array}$ & 75 & 18 & 24.0 \\
\hline 54. & & Sonet & 46 & 1 & 2.2 \\
\hline 55. & & Iskandar & 85 & 5 & 5.9 \\
\hline 56. & & $227-09$ & 74 & 1 & 1.4 \\
\hline
\end{tabular}




\begin{tabular}{|c|c|c|c|c|c|}
\hline \multirow{2}{*}{ № } & \multicolumn{2}{|c|}{ Combination } & \multirow{2}{*}{$\begin{array}{l}\text { The number of } \\
\text { hybridized } \\
\text { flowers, pieces }\end{array}$} & \multicolumn{2}{|c|}{$\begin{array}{c}\text { The number of } \\
\text { hybridized seeds }\end{array}$} \\
\hline & o & 0 & & pieces & $\%$ \\
\hline 57. & Sanam & Iskandar & 150 & 2 & 1.3 \\
\hline 58. & \multirow{3}{*}{ Nukus-2 } & Chongwan & 40 & 0 & 0 \\
\hline 59. & & Iskandar & 90 & 11 & 12.2 \\
\hline 60. & & Osmancik-97 & 33 & 12 & 36.4 \\
\hline 61. & \multirow{3}{*}{ Osmancik-97 } & Chongwan & 110 & 0 & 0 \\
\hline 62. & & Iskandar & 95 & 0 & 0 \\
\hline 63. & & $\begin{array}{c}\text { TSHD 26-13-1-1-1- } \\
1 \\
\end{array}$ & 50 & 0 & 0 \\
\hline 64. & \multirow{3}{*}{$\begin{array}{c}\text { TSHD 15-13- } \\
1-1-1-1\end{array}$} & Chongwan & 70 & 0 & 0 \\
\hline 65. & & Iskandar & 105 & 7 & 67 \\
\hline 66. & & Sonet & 130 & 8 & 6.2 \\
\hline 67. & \multirow{3}{*}{ Sitora } & $\begin{array}{c}\text { TSHD 15-13-1-1-1- } \\
1\end{array}$ & 70 & 2 & 2.9 \\
\hline 68. & & Iskandar & 50 & 1 & 2.0 \\
\hline 69. & & $\begin{array}{c}\text { TSHD 20-13-1-1-1- } \\
1\end{array}$ & 85 & 2 & 2.4 \\
\hline 70. & Dunay & Iskandar & 150 & 0 & 0 \\
\hline 71. & \multirow{4}{*}{ IRRI 147} & Chongwang & 120 & 8 & 6.7 \\
\hline 72. & & Kuraj & 65 & 4 & 6.2 \\
\hline 73. & & Xitoy & 52 & 0 & 0 \\
\hline 74. & & Osmanchik & 41 & 0 & 0 \\
\hline 75. & \multirow{4}{*}{ Osmanchik } & TSHD 8-14 & 60 & 0 & 0 \\
\hline 76. & & TSHD 15-13-1 & 50 & 0 & 0 \\
\hline 77. & & Xitoy & 50 & 0 & 0 \\
\hline 78. & & Diamond & 75 & 0 & 0 \\
\hline 79. & \multirow{4}{*}{ TSHD 8-14 } & Qora-qiltiq & 86 & 0 & 0 \\
\hline 80. & & Osmanchik & 56 & 0 & 0 \\
\hline 81. & & Iskandar & 22 & 0 & 0 \\
\hline 82. & & Novator & 22 & 0 & 0 \\
\hline 83. & \multirow{3}{*}{ Polizesti } & TSHD 8-14 & 88 & 7 & 8.0 \\
\hline 84. & & Lazurniy & 56 & 0 & 0 \\
\hline 85. & & Qora-qiltiq & 30 & 0 & 0 \\
\hline 86. & \multirow{2}{*}{ Taebaek } & Xitoy 2 & 30 & 2 & 6.7 \\
\hline 87. & & Iskandar & 52 & 0 & 0 \\
\hline 88. & TSHD 15-13-1 & Novator & 44 & 1 & 2.3 \\
\hline
\end{tabular}




\begin{tabular}{|c|c|c|c|c|c|}
\hline \multirow{2}{*}{ № } & \multicolumn{2}{|c|}{ Combination } & \multirow{2}{*}{$\begin{array}{l}\text { The number of } \\
\text { hybridized } \\
\text { flowers, pieces }\end{array}$} & \multicolumn{2}{|c|}{$\begin{array}{l}\text { The number of } \\
\text { hybridized seeds }\end{array}$} \\
\hline & 우 & $\hat{0}$ & & pieces & $\%$ \\
\hline 89. & & Diamond & 10 & 0 & 0 \\
\hline 90. & & Osmanchik & 10 & 0 & 0 \\
\hline 91. & & Koreya & 20 & 0 & 0 \\
\hline 92. & Novator & Lazurniy & 90 & 12 & 13.3 \\
\hline 93. & \multirow{3}{*}{ TSHD 26-13 } & Osmanchik & 85 & 11 & 12.9 \\
\hline 94. & & Qora-qiltiq & 42 & 0 & 0 \\
\hline 95. & & Chongwang & 31 & 0 & 0 \\
\hline 96. & \multirow{3}{*}{ Lazurniy } & Chongwang & 90 & 8 & 8.9 \\
\hline 97. & & Xitoy 2 & 12 & 1 & 8.3 \\
\hline 98. & & Kuraj & 20 & 0 & 0 \\
\hline 99. & \multirow{4}{*}{ Polizesti } & Osmanchik & 30 & 2 & 6.7 \\
\hline 100 & & Kuraj & 20 & 0 & 0 \\
\hline 101 & & Lazurniy & 20 & 0 & 0 \\
\hline 102 & & TSHD 15-13 & 20 & 0 & 0 \\
\hline 103 & \multirow{4}{*}{ Dongjin } & Lazurniy & 20 & 1 & 5.0 \\
\hline 104 & & Osmanchik & 20 & 2 & 10.0 \\
\hline 105 & & Iskandar & 25 & 0 & 0 \\
\hline 106 & & Nukus-2 & 15 & 0 & 0 \\
\hline 107 & \multirow{3}{*}{ Tarona } & Kuraj & 85 & 8 & 9.4 \\
\hline 108 & & Navator & 150 & 12 & 8.0 \\
\hline 109 & & Chongwang & 50 & 2 & 4.0 \\
\hline & Total & & 7172 & 316 & 4.40 \\
\hline
\end{tabular}

Seeds of $F_{1}$ hybrid population obtained as a result of crossbreeding were planted and maintained. Clearly, they were collected in a thermostat at $27{ }^{\circ} \mathrm{C}$ for 7 days in the laboratory (Figure 8), and the harvested plants were transferred to paper pots filled with fine soil and kept for 15 days, 3 . When the plants had 2-3 leaves, they were planted in the field and cared for side by side with the parent forms. Seeds of $4 \mathrm{~F}_{2}, 75 \mathrm{~F}_{3}-\mathrm{F}_{6}$ generation hybrid populations and 17 individual selection seeds were sown in 6 rows per $2 \mathrm{~m}^{2}$ area at a rate of 500 seeds $/ \mathrm{m}^{2}$. Phenological and morphological observations were made at all phases of the growing season (germination, accumulation, tubing, flowering and ripening) of hybrid populations using the Pedigree method. The hybrid lines were planted in the first year together with the parent form and the characteristics were compared and evaluated. In the second and subsequent generations of the hybrid generations, work continued on the selection of lines with valuable character traits. 


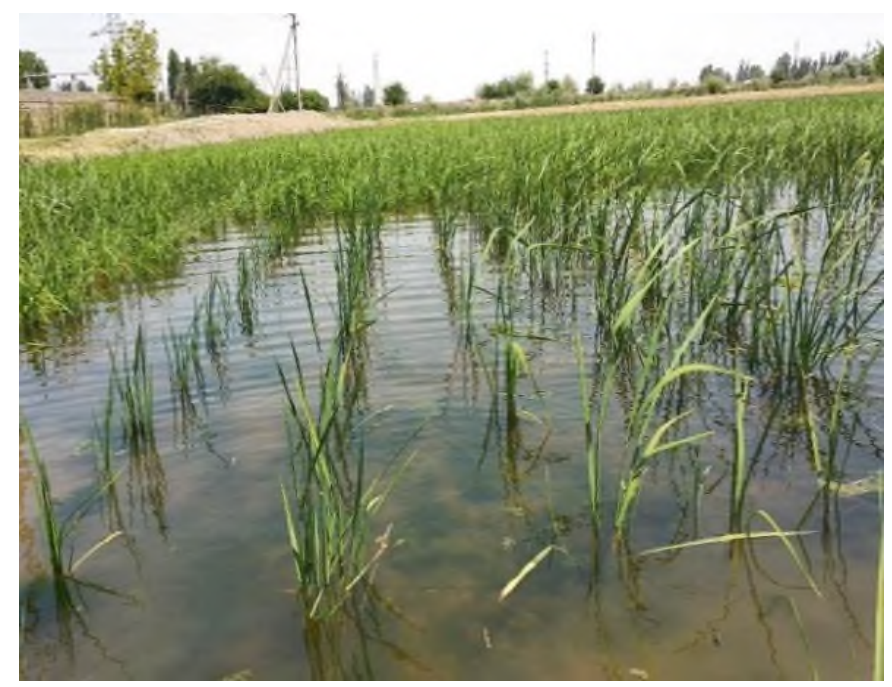

Fig. 8. Caring for hybrid offspring by planting them side by side.

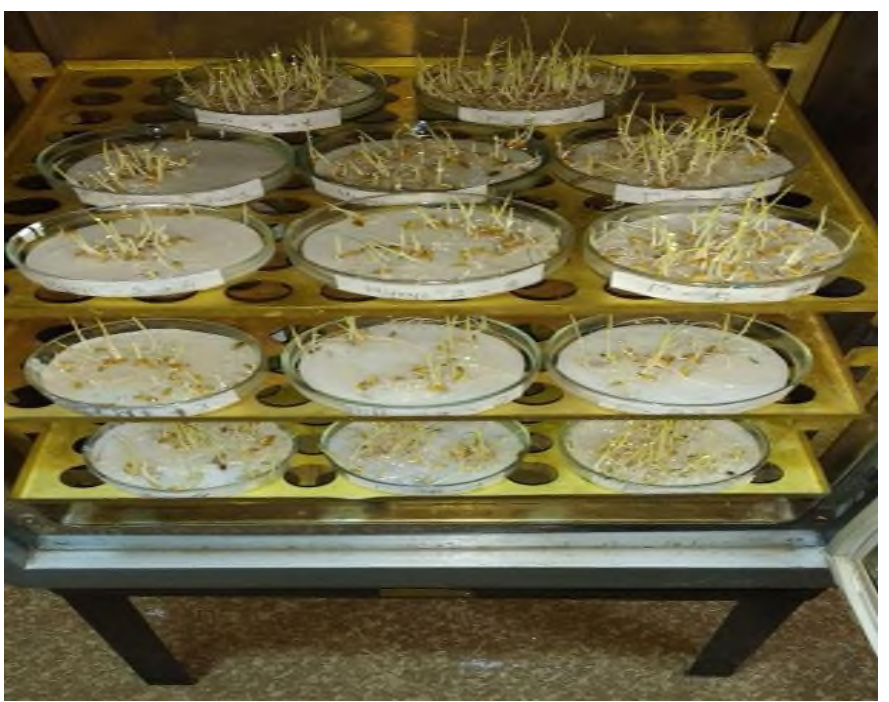

Fig. 9. Extraction of F1 generation hybrid offsets in a thermostat under laboratory conditions

The observation results showed that 20 hybrids from $\mathrm{F}_{2}$ generation hybrid populations, 29 hybrids from $F_{3}-F_{7}$ generation hybrid populations, a total of 49 hybrids were selected on morphological and biometric indicators and identified for use in selection work in subsequent years. The dominance of plant height, stalk length, and grain weight per 1000 grains in the F1 generation hybrid combinations studied was determined. The plant height in F1 generation hybrids was $104.3-132 \mathrm{~cm}$, with a low level of dominance in Chongwang x 227-09 and Polizesti x Alexander combinations, and a high level of dominance in TShD 15-13 x Iskandar and Sanam x Iskandar combinations. In $F_{1}$ generation hybrids, the stalk length was $18.2-23.4 \mathrm{~cm}$, with a low degree of dominance in the combinations Chongwang $\mathrm{x}$ TShD 15-13 and Chongwang $\mathrm{x}$ 227-09, and a high degree of dominance in the 
combinations TShD 15-13 x Iskandar and Sitora $\mathrm{x}$ Iskandar was observed. In $\mathrm{F}_{1}$ generation hybrids, the grain weight per 1000 grains was $27.9-34.8 \mathrm{~g}$, with a low degree of dominance in the combinations of Chongwang x TShD 15-13, Chongwang x 227-09 and Polizesti $x$ Iskandar, Sitora x TShD 20-13 and Nukus- In the 2 x Alexander combinations, a higher degree of dominance was observed. In $\mathrm{F}_{1}$ generation hybrids obtained from combinations of Chongwang x TShD 15-13 and Chongwang x 227-09, it was recommended not to use these combinations in future studies due to the low dominance of rye length and 1000 grain weight (Table 4).

Table 4. Dominance in plant height, rhizome length, and 1000 grain weight in $\mathrm{F}_{1}$ generation hybrids

\begin{tabular}{|c|c|c|c|c|c|c|c|c|c|c|c|c|c|}
\hline \multirow{2}{*}{ № } & \multirow{2}{*}{$\begin{array}{c}\text { Name of } \\
\text { combinations }\end{array}$} & \multicolumn{4}{|c|}{ Plant height, cm } & \multicolumn{4}{|c|}{ "Ruvak" height, cm } & \multicolumn{4}{|c|}{$\begin{array}{l}\text { Weight of } 1000 \\
\text { grain, gr }\end{array}$} \\
\hline & & $q$ & $\hat{0}$ & $\mathbf{F}_{1}$ & hp & o & $\hat{0}$ & $\mathbf{F}_{1}$ & hp & 우 & $\hat{0}$ & $\mathbf{F}_{1}$ & hp \\
\hline 1 & $\begin{array}{c}\text { Jinbu } \mathrm{x} \\
\text { Chongwang }\end{array}$ & $\begin{array}{c}93 . \\
4\end{array}$ & $\begin{array}{c}105 \\
.6\end{array}$ & $\begin{array}{c}104 . \\
3\end{array}$ & $\begin{array}{c}0.7 \\
9\end{array}$ & $\begin{array}{c}16 . \\
4\end{array}$ & $\begin{array}{c}17 . \\
8\end{array}$ & $\begin{array}{c}18 . \\
2\end{array}$ & 1.6 & $\begin{array}{c}26 \\
.1\end{array}$ & $\begin{array}{c}28 \\
.9\end{array}$ & $\begin{array}{r}27 \\
.9\end{array}$ & 0.29 \\
\hline 2 & $\begin{array}{c}\text { TSHD 20-13 x } \\
\text { TSHD } 15-13\end{array}$ & $\begin{array}{c}131 \\
.4\end{array}$ & $\begin{array}{c}124 \\
.2\end{array}$ & $\begin{array}{c}130 . \\
2\end{array}$ & $\begin{array}{c}0.6 \\
7\end{array}$ & $\begin{array}{c}20 . \\
1\end{array}$ & $\begin{array}{c}21 . \\
5\end{array}$ & $\begin{array}{c}21 . \\
7\end{array}$ & 1.3 & $\begin{array}{c}31 \\
.1\end{array}$ & 33 & $\begin{array}{l}31 \\
.8\end{array}$ & 0.26 \\
\hline 3 & $\begin{array}{c}\text { Sitora } \mathrm{x} \\
\text { TSHD 20-13 }\end{array}$ & $\begin{array}{c}132 \\
.2\end{array}$ & $\begin{array}{c}131 \\
.4\end{array}$ & 132 & $\begin{array}{c}0.5 \\
0\end{array}$ & $\begin{array}{c}22 . \\
5\end{array}$ & $\begin{array}{c}20 . \\
1\end{array}$ & $\begin{array}{c}21 . \\
6\end{array}$ & 0.3 & $\begin{array}{r}34 \\
.4\end{array}$ & $\begin{array}{c}31 \\
.1\end{array}$ & $\begin{array}{c}34 \\
.8\end{array}$ & 1.24 \\
\hline 4 & $\begin{array}{c}\text { TSHD15-13 x } \\
\text { Sanam }\end{array}$ & $\begin{array}{c}124 \\
.2\end{array}$ & $\begin{array}{c}106 \\
.8\end{array}$ & $\begin{array}{c}123 . \\
2\end{array}$ & $\begin{array}{c}0.8 \\
9\end{array}$ & $\begin{array}{c}21 . \\
5\end{array}$ & $\begin{array}{c}19 . \\
7\end{array}$ & $\begin{array}{c}22 . \\
1\end{array}$ & 1.7 & 33 & $\begin{array}{l}31 \\
.6\end{array}$ & $\begin{array}{l}32 \\
.8\end{array}$ & 0.71 \\
\hline 5 & $\begin{array}{c}\text { Chongwang } \mathrm{x} \\
\text { TSHD15-13 }\end{array}$ & $\begin{array}{c}105 \\
.6\end{array}$ & $\begin{array}{c}124 \\
.2\end{array}$ & $\begin{array}{c}115 . \\
2\end{array}$ & $\begin{array}{c}0.0 \\
3\end{array}$ & $\begin{array}{c}17 . \\
8\end{array}$ & $\begin{array}{c}21 . \\
5\end{array}$ & $\begin{array}{c}18 . \\
9\end{array}$ & $\begin{array}{l}- \\
0.4\end{array}$ & $\begin{array}{c}28 \\
.9\end{array}$ & 33 & $\begin{array}{l}30 \\
.5\end{array}$ & $\overline{-}$ \\
\hline 6 & $\begin{array}{c}\text { Sitora } \mathrm{x} \\
\text { TSHD15-13 }\end{array}$ & $\begin{array}{c}132 \\
.2\end{array}$ & $\begin{array}{c}124 \\
.2\end{array}$ & $\begin{array}{c}130 . \\
9\end{array}$ & $\begin{array}{c}0.6 \\
8\end{array}$ & $\begin{array}{c}22 . \\
5\end{array}$ & $\begin{array}{c}21 . \\
5\end{array}$ & $\begin{array}{c}22 . \\
9\end{array}$ & 1.8 & $\begin{array}{r}34 \\
.4\end{array}$ & 33 & $\begin{array}{l}34 \\
.1\end{array}$ & 0.57 \\
\hline 7 & $\begin{array}{l}\text { Sitora } \mathrm{x} \\
\text { Iskandar }\end{array}$ & $\begin{array}{c}132 \\
.2 \\
\end{array}$ & $\begin{array}{c}126 \\
.6 \\
\end{array}$ & $\begin{array}{c}130 . \\
7\end{array}$ & $\begin{array}{c}0.4 \\
6 \\
\end{array}$ & $\begin{array}{c}22 . \\
5\end{array}$ & $\begin{array}{c}22 . \\
2\end{array}$ & $\begin{array}{c}23 . \\
1\end{array}$ & 5.0 & $\begin{array}{r}34 \\
.4 \\
\end{array}$ & $\begin{array}{l}33 \\
.6 \\
\end{array}$ & $\begin{array}{l}34 \\
.2 \\
\end{array}$ & 0.50 \\
\hline 8 & $\begin{array}{c}\text { Chongwang } \mathrm{x} \\
227-09\end{array}$ & $\begin{array}{c}105 \\
.6\end{array}$ & $\begin{array}{c}130 \\
.1\end{array}$ & $\begin{array}{c}116 . \\
5\end{array}$ & $\begin{array}{c}- \\
0.1 \\
1\end{array}$ & $\begin{array}{c}17 . \\
8\end{array}$ & $\begin{array}{c}21 . \\
8\end{array}$ & $\begin{array}{c}19 . \\
5\end{array}$ & 0.2 & $\begin{array}{c}28 \\
.9\end{array}$ & $\begin{array}{r}34 \\
.5\end{array}$ & $\begin{array}{l}30 \\
.2\end{array}$ & - \\
\hline 9 & $\begin{array}{c}\text { TSHD } 15-13 \mathrm{x} \\
\text { Iskandar } \\
\end{array}$ & $\begin{array}{c}124 \\
.2 \\
\end{array}$ & $\begin{array}{c}126 \\
.6 \\
\end{array}$ & $\begin{array}{c}127 . \\
4 \\
\end{array}$ & $\begin{array}{c}1.6 \\
7 \\
\end{array}$ & $\begin{array}{c}21 . \\
5\end{array}$ & $\begin{array}{c}22 . \\
2\end{array}$ & $\begin{array}{c}23 . \\
1\end{array}$ & 3.6 & 33 & $\begin{array}{l}33 \\
.6 \\
\end{array}$ & $\begin{array}{l}33 \\
.4 \\
\end{array}$ & 0.33 \\
\hline 10 & $\begin{array}{l}\text { Polizesti x } \\
\text { Iskandar }\end{array}$ & $\begin{array}{c}122 \\
.5\end{array}$ & $\begin{array}{c}126 \\
.6\end{array}$ & $\begin{array}{c}123 . \\
1\end{array}$ & $\begin{array}{c}- \\
0.7 \\
1\end{array}$ & $\begin{array}{c}19 . \\
8\end{array}$ & $\begin{array}{c}22 . \\
2\end{array}$ & $\begin{array}{c}21 . \\
8\end{array}$ & 0.7 & $\begin{array}{l}32 \\
.9\end{array}$ & $\begin{array}{l}33 \\
.6\end{array}$ & $\begin{array}{r}33 \\
.0\end{array}$ & $0 . \overline{71}$ \\
\hline 11 & $\begin{array}{l}\text { Nukus-2 x } \\
\text { Iskandar }\end{array}$ & $\begin{array}{c}98 . \\
1\end{array}$ & $\begin{array}{c}126 \\
.6\end{array}$ & $\begin{array}{c}125 . \\
5\end{array}$ & $\begin{array}{c}0.9 \\
2\end{array}$ & $\begin{array}{c}17 . \\
5\end{array}$ & $\begin{array}{c}22 . \\
2\end{array}$ & $\begin{array}{c}22 . \\
8\end{array}$ & 1.3 & $\begin{array}{r}28 \\
.6\end{array}$ & $\begin{array}{r}33 \\
.6\end{array}$ & $\begin{array}{r}33 \\
.5\end{array}$ & 0.96 \\
\hline 12 & $\begin{array}{l}\text { Sanam x } \\
\text { Iskandar }\end{array}$ & $\begin{array}{c}106 \\
.8\end{array}$ & $\begin{array}{c}126 \\
.6\end{array}$ & $\begin{array}{c}126 . \\
4\end{array}$ & $\begin{array}{c}0.9 \\
8\end{array}$ & $\begin{array}{c}19 . \\
7\end{array}$ & $\begin{array}{c}22 . \\
2\end{array}$ & $\begin{array}{c}23 . \\
4\end{array}$ & 2.0 & $\begin{array}{r}31 \\
.6\end{array}$ & $\begin{array}{r}33 \\
.6\end{array}$ & $\begin{array}{l}33 \\
.1\end{array}$ & 0.50 \\
\hline 13 & $\begin{array}{l}\text { TSHD 20-13 x } \\
\text { Iskandar }\end{array}$ & $\begin{array}{c}131 \\
.4\end{array}$ & $\begin{array}{c}126 \\
.6\end{array}$ & $\begin{array}{c}128 . \\
4\end{array}$ & $\begin{array}{c}0.2 \\
5\end{array}$ & $\begin{array}{c}20 . \\
1\end{array}$ & $\begin{array}{c}22 . \\
2\end{array}$ & 23 & 1.8 & $\begin{array}{c}31 \\
.1\end{array}$ & $\begin{array}{r}33 \\
.6\end{array}$ & $\begin{array}{l}32 \\
.9\end{array}$ & 0.44 \\
\hline
\end{tabular}

\section{CONCLUSION}

In 2018-2020, 425 varieties were planted in the collection nursery as a standard, Guljahon for early maturing groups, Iskandar for middle maturing groups, UzROS 7-13 and Tarona for late maturing groups were studied and compared. The vegetation period of the selected varieties was 105 days in the very early group, 105 to 115 days in the early group, 115 to 125 days in the middle group, and 125 days or more in the late group. In 
addition, of the 30 selected varieties per 1000 grain weight from the ultra-early group k-243 $(30.5 \mathrm{~g}), \mathrm{k}-270(32.8 \mathrm{~g})$ and k-297 (35.2 g), from the early-maturing group k -268 (33.4 g), $\mathrm{k}-231(34.7 \mathrm{~g})$ and k-82 (32.3 g), from the middle-aged group k-43 (34.5 g), k-223 (33.9 g) and k-389 (36.1 g) and k-103 (35.5 g) from the late ripening group, were selected.

The results represented that 4217 varieties in 2018, 28 varieties in 2019 and 39 varieties in 2020 with a total of 109 combinations were selected with the participation of selected varieties and specimens that were resistant to various environmental influences and diseases, high yield, high grain quality. According to the results of the hybridization, 118 (or 3.78\%) in 2018, 117 (or 5.35\%) in 2019, 81 (or 4.35\%) in 2020, a total of 316 (or 4.4\%) hybrid populations were taken. $F_{1}$ generation hybrids obtained from the combinations of Chongwang x TShD 15-13 and Chongwang x 227-09, was recommended not to use these combinations in future studies due to the low dominance of "Ruvak" (paniculo is a type of plant inflorescence) length and 1000 grain weight.

\section{References}

1. T. Thomas, J. Purushothaman, R. Janarthanan, N. Anusuya, P. G. Medisetti, J. Karthick, S. Thirumeni, Plant Physiology Reports 25, 4 (2020)

2. H. Bhandari, the Korean Society of Crop Science, 11 (2019)

3. Presidential Decree No.4947 of the Republic of Uzbekistan on "The strategy of action for the development of the republic of Uzbekistan" on February 7 (2017)

4. V. A. Dzyuba, Manual Krasnodar, 974-980 (2010)

5. G. L. Zelensky, A. G. Zelensky, S. S. Skorkina, T. A. Romashchenko, V. V. Tsogoeva, Rice farming 3-4, 32-33 (2016)

6. M. A. Skazhennik, V. A. Dzyuba, V. S. Kovalev, S. V. Garkusha, E. V. Dubina, I. N. Chukhir, E. G. Savenko, Rice farming 3, 36 (2017)

7. N. G. Tumanyan, the scientific journal of the Kuban state agrarian University 94, 10 (2013)

8. M. V. Shatalova, the scientific journal of the Kuban state agrarian University 133, 9 (2017)

9. B. Alasgarov, M. Hayitov, M. Rahmonov, AGRO ILM 1, 51 (2018)

10. S. W. Abeysekera, S. N. Jayawardena, Proceedings of the 6th International Hybrid Rice Symposium, 48-58 (2012) 